Article

\title{
Surface Sediment Diatom Assemblages Response to Water Environment in Dongping Lake, North China
}

\author{
Shuangshuang Liu ${ }^{1,2,3}$, Min Yao ${ }^{4}$, Shiyue Chen ${ }^{5, *}$ and Xingzhong Yuan ${ }^{1,2, *}$ \\ 1 School of Architectural and Urban Planning, Chongqing University, Chongqing 400030, China; \\ 20142001002@cqu.edu.cn \\ 2 Key Laboratory of New Technology for Construction of Cities in Mountain Area, Chongqing University, \\ Chongqing 400030, China \\ 3 Key Laboratory of the Three Gorges Reservoir Region's Eco-Environment, Ministry of Education, \\ Chongqing University, Chongqing 400030, China \\ 4 School of Environment and Planning, Liaocheng University, Liaocheng 252059, China; MYao@lcu.edu.cn \\ 5 School of City and Environment, Jiangsu Normal University, Xuzhou 221116, China \\ * Correspondence: chenshiyue@jsnu.edu.cn (S.C.); xzyuan@cqu.edu.cn (X.Y.)
}

check for updates

Citation: Liu, S.; Yao, M.; Chen, S.; Yuan, X. Surface Sediment Diatom Assemblages Response to Water Environment in Dongping Lake, North China. Water 2021, 13, 339. https://doi.org/10.3390/w13030339

Received: 7 January 2021

Accepted: 22 January 2021

Published: 29 January 2021

Publisher's Note: MDPI stays neutral with regard to jurisdictional claims in published maps and institutional affiliations.

Copyright: (c) 2021 by the authors. Licensee MDPI, Basel, Switzerland. This article is an open access article distributed under the terms and conditions of the Creative Commons Attribution (CC BY) license (https:// creativecommons.org/licenses/by/ $4.0 /)$.

\begin{abstract}
The relationship between the diatom taxa preserved in surface lake sediments and environmental variables in Dongping Lake was explored using multivariate statistical methods. The statistical analysis showed that the lake was eutrophicated in all seasons. Transparency, chlorophyll a (Chla) and total phosphorus (TP) were the dominant environmental factors in spring and summer, and $\mathrm{NH}_{4}{ }^{+}-\mathrm{N}$ and chemical oxygen demand (COD) were the dominant environmental factors in autumn and winter. Sixteen genera and 43 species of diatom were found in the surface sediments, and the dominant diatom genera were Aulacoseira, Ulnaria, Cyclotella, Navicula and Fragilaria. A redundancy analysis (RDA) and Monte Carlo permutation 20 test revealed that COD, pH, TP, conductivity and transparency were significant factors influencing diatom assemblage change, meaning that the distribution of the diatom assemblages were mostly influenced by nutrient composition, light intensity and ion concentrations.
\end{abstract}

Keywords: Dongping Lake; water environment; surface sediment; limnology; diatom; redundancy analysis

\section{Introduction}

As an important element of aquatic ecosystems, phytoplanktons have been widely used as indicators of the quality of the water environment (especially the salinity level) in paleoecological studies [1-3]. Diatoms have specific optimal levels and degrees of tolerance to some indicators of the water environment (such as $\mathrm{pH}$, temperature, salinity and nutrients) $[1,4,5]$, so changes in these variables will affect their community structure and biomass, making them a reliable indicator of water quality, including the occurrence of acidification and eutrophication [6-8].

Dongping Lake is the second largest freshwater lake in Shandong Province, North China, and it is also a regulatory reservoir of the South-to-North Water Diversion Project of China and a water catchment area of the West-to-East Water Transmission Project of Shandong Province. However, in recent years, plant communities have declined dramatically due to feeding by a large number of herbivorous fish and damage to aquatic plants $[9,10]$. Additionally, the diversity of aquatic plant species has decreased significantly due to water pollution and eutrophication, and emergent plants have largely disappeared [11,12]. The distribution of Trapaceae and Nymphaeaceae continues to migrate to the east, away from expanding cage aquaculture areas on the west side of the lake [13-16]. In addition, because of the rapid development of the regional economy, the expansion of cage aquaculture and the increase in the human population, Dongping Lake has experienced eutrophication [17]. 
As a result of the complex interactions between diatoms and the aquatic environment in Dongping Lake, each diatom species has been recorded under a certain set of environmental conditions and thus will respond to changes in environmental characteristics. Although there have been many studies of the environmental state of Dongping Lake, most have focused on the monitoring and evaluation of water quality using physical and chemical factors [18-20]. The use of multivariate direct gradient analysis to reveal the present condition of the ecological environment has been rare for Dongping Lake. Lake ecosystem health is still a hot topic in ecology. In this study, we analyzed the diatomenvironment index in the surface sediments to reveal the relationship between diatom community structure and the water environment, which is useful for determining the community structure composition, dominant species and population distribution, helping to predict how diatom populations will respond to changes in the water environment. A long-term study of dynamic changes in lake water quality and the plankton-algal community will provide a theoretical basis for water quality safety and bloom prevention. This study focuses on the surface sediment diatom assemblage (i.e., a spatial survey of present conditions) rather than a paleolimnological survey, which may provide information regarding long-term changes in diatom assemblage composition and also provide data support for lake ecosystem health and biodiversity restoration.

\section{Materials and Methods}

\subsection{Study Area}

Dongping Lake $\left(35^{\circ} 30^{\prime}-36^{\circ} 20^{\prime} \mathrm{N}, 116^{\circ} 00^{\prime}-116^{\circ} 30^{\prime} \mathrm{E}\right)$ is located in Dongping County of Taian City, Shandong Province. Historically, it was known as the Daye Swamp, but it was named the Juye River from the Spring and Autumn Period until the Han Dynasty. Dongping Lake is the only remaining large natural inland lake after thousands of years of geological and geomorphological changes in the lower reaches of the Yellow River [21]. It is mainly affected by a warm and semi-humid continental monsoonal climate, with four distinct seasons and abundant precipitation. The mean annual precipitation is $640 \mathrm{~mm}$, with maximum and minimum values of $1394.8 \mathrm{~mm}$, and $261.6 \mathrm{~mm}$. The precipitation in this area is characterized by uneven seasonal distribution. It is most concentrated in summer, with precipitation in July and August being more than half of the annual total precipitation. The annual average temperature in this area is $13.4^{\circ} \mathrm{C}$, with an annual average maximum temperature of $20^{\circ} \mathrm{C}$, and an average daily range of $9.0-13^{\circ} \mathrm{C}$, the temperature difference between day and night is the largest in spring and the smallest in summer. The water of Dongping Lake is yellow-green in color, with water transparency ranging from 0.20 to $1.46 \mathrm{~m}$, with an average $0.58 \mathrm{~m}$, and the multi-annual mean depth of Dongping Lake is 2-4 m (Compling Team for Annals of Dongping County Shandong Province 2006). Dongping Lake is the second largest freshwater lake (compared to Nansi Lake) in Shandong Province, its current size being approximately $627 \mathrm{~km}^{2}$. The entire lake consists of a new lake and an old lake, separated by the secondary lake embankment. The new lake is used for flood detention, mainly to protect low-lying agricultural land. The old lake is an impounding area with an average water depth of about $2.5 \mathrm{~m}$ and an area of about $160 \mathrm{~km}^{2}$, the annual impounded area is $124 \mathrm{~km}^{2}$ [22]. The research area referred to in this paper is the old lake, which is the concentrated area of lake wetlands. Dongping Lake became a regulating reservoir with the implementation of the South-to-North Water Diversion Project of China and a water catchment area for the West-to-East Water Transmission Project of Shandong Province. The lake has strategic significance, so the safety of the water environment must be guaranteed. Apart from tourism, Dongping Lake is primarily used as a water supply for aquaculture, irrigation and flood control. It is also a spawning ground for economically important freshwater fish.

\subsection{Sampling and Laboratory Techniques}

A total of 32 sites were sampled in April, August, October and December 2014 separately; sites were selected to cover most of the area of Dongping Lake (Figure 1). Water 
samples were collected for chemical analyses at a depth of $0.5 \mathrm{~m}$ below the lake surface using polyethylene bottles and samples were transported to the laboratory within $24 \mathrm{~h}$. Surface sediment samples were collected using a modified Kajak-Brinkhurst corerand the uppermost $0.5 \mathrm{~cm}$ of sediments were used for diatom counts and species identification. Dissolved oxygen (DO), water temperature $(\mathrm{T}), \mathrm{pH}$, conductivity were measured in situ with HACH (HQ30d, America), water depth was measured with a hand-held sonar depth finder, SM-5A (Speedtech, America), and water transparencies were measured with a Secchi disc.

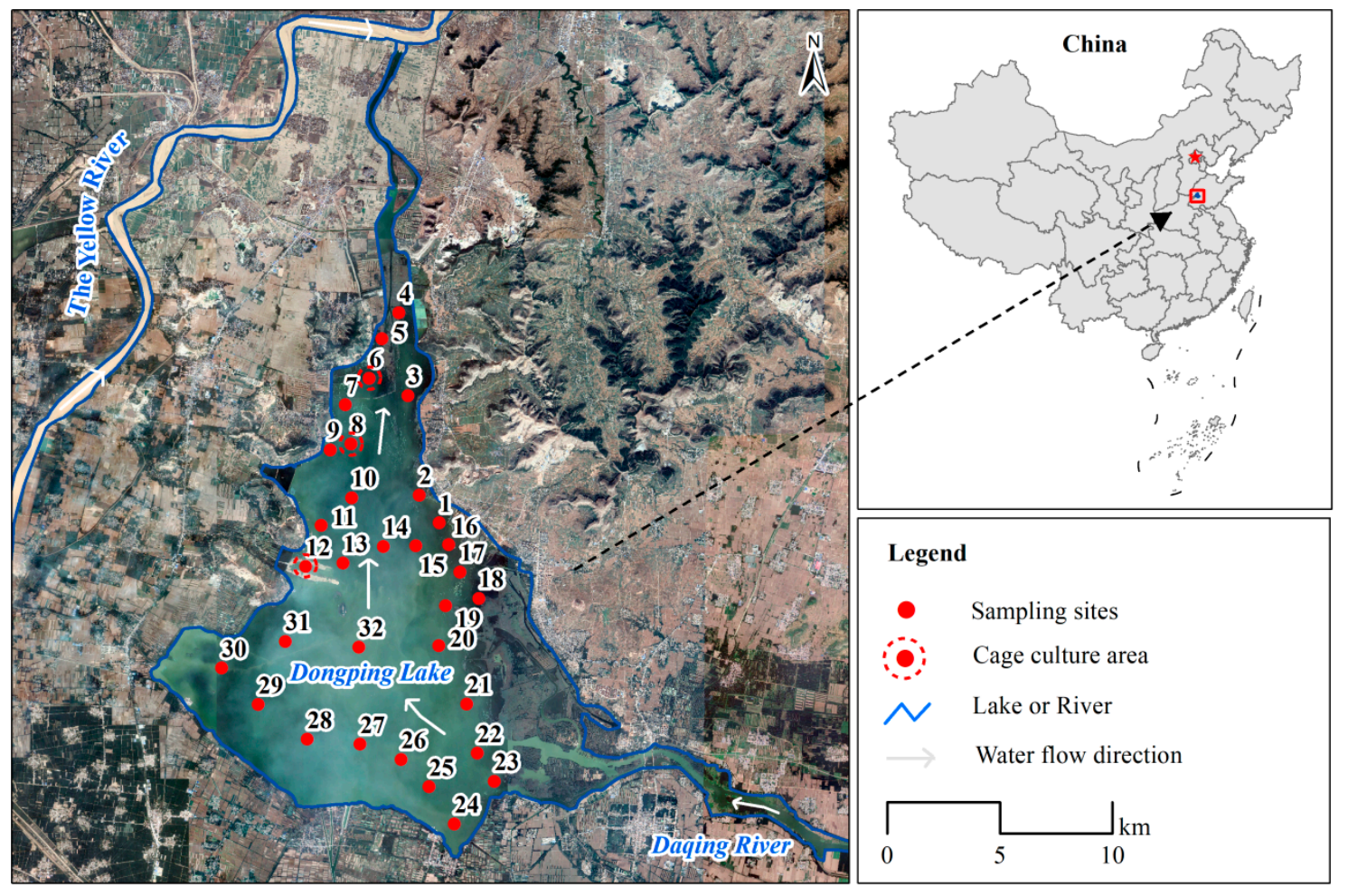

Figure 1. Sampling sites at Dongping Lake.

The analyses in this study followed the standards of the National Environment Protection Agency of China (NEPAC). Total nitrogen (TN), nitrate $\left(\mathrm{NO}_{3}{ }^{-}\right)$and ammonia nitrogen $\left(\mathrm{NH}_{4}{ }^{+}-\mathrm{N}\right)$ were determined using a FIA $6000+$ flow injection analyzer (Beijing, China). Total phosphorus (TP) was measured using an ion chromatograph (SHINE, Qingdao, China). The chemical oxygen demand (COD) was determined using the acidic potassium permanganate method, and chlorophyll a (Chla) was extracted with acetone (National Environmental Protection Agency of China (NEPAC) 2002) [23].

The surface sediments used for diatom species identification were treated with hydrochloric acid $(10 \%)$ and hydrogen peroxide according to the method of Battarbee and Charles (1986) [24] and permanent diatom mounts were made from cleaned materials for identification and counting under light microscopy. The diatom taxa were identified according to Krammer and Lange-Bertalot $(1986,1988,1991 a, b)$ [25-28], the diversity of diatom assemblages was estimated from the total number of taxa in each sample and the relative abundance of diatom taxa was analyzed by counting at least 300 valves per sample. The relative abundance was expressed as a percentage.

\subsection{Statistical Analysis}

We use the trophic state index (TSI) as an overall indicator of water quality by allocating a trophic class based on environmental measurements. In this study, the TSI adopted corresponded to that used by Carlson's amended index [29] for the classification of environments. Evaluation formulas for eutrophication were shown in Table 1. Total 
phosphorus (TP), total nitrogen and chlorophyll a (Chla) concentration (in $\mathrm{mg} / \mathrm{L}$ ) provide alternative TSI values, from which an average TSI can be determined.

$$
\begin{gathered}
\text { TSI }_{\text {Chla }}=10\{6-[2.04-0.68 \ln (\text { Chla })] / \ln 2\} \\
T S I_{T P}=10\{6-[\ln (48 / T P) / \ln 2]\} \\
T S I_{T N}=10\{6-[\ln (1.47 / T N) / \ln 2]\} \\
T S I=\left(T S I_{C h l a}+T S I_{T P}+T S I_{T N}\right) / 3
\end{gathered}
$$

Table 1. Trophic states associating with Carlson's trophic state index (TSI).

\begin{tabular}{cc}
\hline Criterion & Trophic State Index (TSI) \\
\hline$S S I<40$ & Oligotrophic \\
$40 \leq T S I<50$ & Mesotrophic \\
$50 \leq T S I<70$ & Eutrophic \\
$T S I \geq 70$ & Hypereutrophic \\
\hline
\end{tabular}

In Equations (1) to (4): $T S I_{C h l a}, T S I_{T P}$ and $T S I_{T N}$ respectively represent the trophic state index of water Chla, TP and TN. (Chla), (TP) and (TN) are the concentrations of Chla $(\mu \mathrm{g} / \mathrm{L}), T P(\mu \mathrm{g} / \mathrm{L})$ and $T N(\mathrm{mg} / \mathrm{L})$, respectively.

A principal component analysis (PCA) based on correlation matrices (i.e., centered and standardized PCA using equal weighting of all taxa) was carried out on environmental data from the four sampling periods to determine important environmental gradients along which sampling sites vary.

A detrended correspondence analysis (DCA) was applied to detect the dynamic changes in the diatom populations [30]. The species scores were scaled to be weighted averages of the site scores, and rare species were down-weighted. The program inputs included the relative abundances of the diatom taxa that were present in at least two sites and had a relative abundance of $\geq 2 \%$ in at least one sample. In this study, some species, such as Nitzschia dissipata, Nitzschia gracilis, Navicula crytocephala, Navicula viridula, Navicula capitata, Cymbopleura lanceolata, Epithemia adnata and Encyonema silesiacum, had low abundances $(<2 \%)$, so these species were removed from the analysis to avoid impacting the results. The DCA analysis showed that the gradient was less than three times the standard deviation (i.e., 1.46), so the relationship between the composition of the sediment diatoms and the environmental variables was assessed using redundancy analysis (RDA) [31].

RDA is a direct gradient analysis technique that can be used to investigate the relationship between diatom assemblages and associated environmental variables [9,32]. The explanatory environmental variables were square root transformed, and the diatom species data (the response variable) were logarithmically transformed. The statistical significance of the relationship between each variable or group of variables and the species matrix was assessed using Monte Carlo permutation tests (999 unrestricted permutations).

Analysis was carried out using CANOCO for Windows 5.0.

\section{Results}

\subsection{Indicators of the Water Environment}

Considering that a single sampling of diatoms can represent a year's data, we took the seasonal average analysis of lake water quality indicators. Because of sand dredging (now complete), the depth of water was deeper at sites 19 and 25. The annual water depth of the lake was $1.95-3.85 \mathrm{~m}$ at other sites. The water dissolved oxygen (DO) ranged from $0.63 \mathrm{mg} / \mathrm{L}$ to $1.55 \mathrm{mg} / \mathrm{L}$. The annual average temperature was $14.8^{\circ} \mathrm{C}$. Changes in the $\mathrm{pH}$ ranged from 7.5 to 8.2 in different sites, meaning that Dongping Lake is alkaline and that the $\mathrm{pH}$ was in the optimum range for biological growth. The TP and TN concentrations varied widely in Dongping Lake. The annual TN concentration was $1.25-4.58 \mathrm{mg} / \mathrm{L}$ and 
the $\mathrm{NO}_{3}{ }^{-}-\mathrm{N}$ concentration was $0.56-3.35 \mathrm{mg} / \mathrm{L}$. The TP varied significantly in different regions, and the average annual concentration $0.04-0.17 \mathrm{mg} / \mathrm{L}$. The annual average value of COD was 4.0-9.1 mg/L in different sampling sites. The water transparency of Dongping Lake ranged from $0.45 \mathrm{~m}$ to $1.6 \mathrm{~m}$ (Figure 2).
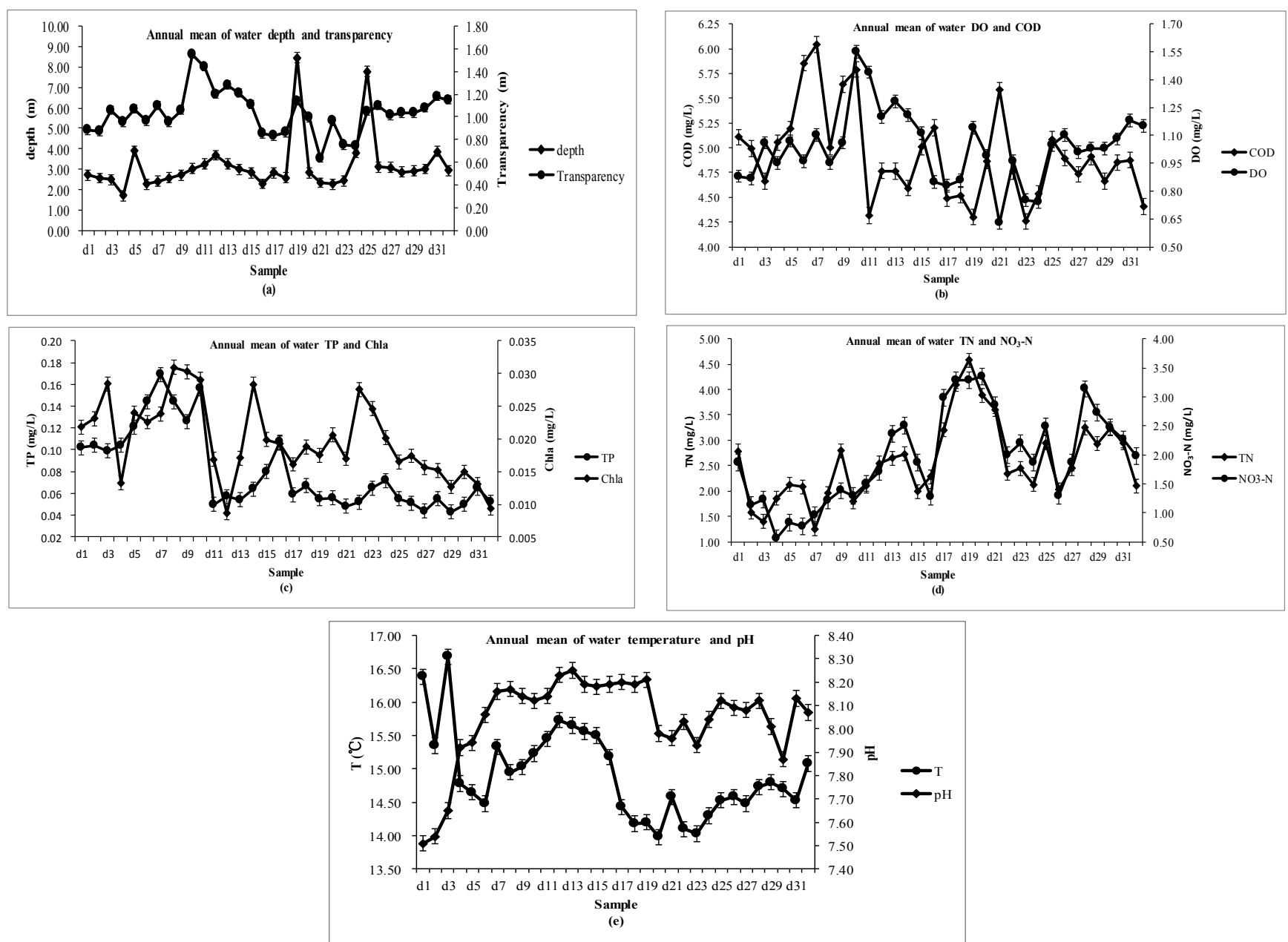

Figure 2. Variation in the annual physicochemical index of Dongping Lake. (a) annual mean of water depth and transparency; (b) annual mean of water DO and COD; (c) annual mean of water TP and Chla; (d) annual mean of water TN and $\mathrm{NO}_{3}{ }^{-}-\mathrm{N} ;(\mathbf{e})$ annual mean of water temperature and $\mathrm{pH}$.

A major strength of TSI is that the interrelationships between variables can be used to identify certain conditions in the lake or reservoir that are related to the factors that limit algal biomass or affect the measured variables. When all variables are measured, it is possible that different index values will be obtained, and such situations were noted for Dongping Lake (Table 2).

The chlorophyll indices varied greatly in different seasons. They were lowest in spring and highest in summer, followed by autumn and winter. Average TSI based on chlorophyll a concentration during the investigated year in Dongping Lake was 54.75, which indicates eutrophic conditions, and the highest value of TSI Chla was recorded in August. The TSI based on TP was 67.47 in summer, 46.62 in spring and there was little difference in autumn and winter. TSI based on TN had little difference in four seasons; the average TSI based on TP was closer to TSI derived from chlorophyll, in comparison with TSI based on TN. Statistics showed that Dongping Lake was in a eutrophication state in four seasons. 
Table 2. Trophic state indices of four seasons in Dongping Lake.

\begin{tabular}{|c|c|c|c|c|c|c|c|c|c|}
\hline & \multicolumn{2}{|c|}{ Spring } & \multicolumn{2}{|c|}{ Summer } & \multicolumn{2}{|c|}{ Autumn } & \multicolumn{2}{|c|}{ Winter } & \multirow[b]{2}{*}{ Annual Average } \\
\hline & Range & Average Value & Range & Average Value & Range & Average Value & Range & Average Value & \\
\hline Chla( $(\mu \mathrm{g} / \mathrm{L})$ & $0.45-5.36$ & 2.14 & $16.99-85.54$ & 51.80 & $8.12-32.67$ & 20.28 & $2.91-11.37$ & 6.73 & 20.24 \\
\hline $\mathrm{TP}(\mu \mathrm{g} / \mathrm{L})$ & $10.00-35.00$ & 18.99 & 52.03-172.18 & 80.55 & $9.48 .00-89.24$ & 35.18 & $9.00-99.00$ & 42.48 & 44.30 \\
\hline $\mathrm{TN}(\mathrm{mg} / \mathrm{L})$ & $0.79-4.33$ & 2.87 & $0.79-4.38$ & 2.96 & $0.61-4.08$ & 2.53 & $0.80-3.70$ & 2.38 & 2.69 \\
\hline TSI Chla & \multicolumn{2}{|c|}{38.61} & \multicolumn{2}{|c|}{69.87} & \multicolumn{2}{|c|}{60.67} & \multicolumn{2}{|c|}{49.85} & 54.75 \\
\hline $\mathrm{TSI}_{\mathrm{TP}}$ & \multicolumn{2}{|c|}{46.62} & \multicolumn{2}{|c|}{67.47} & \multicolumn{2}{|c|}{55.52} & \multicolumn{2}{|c|}{58.24} & 56.96 \\
\hline $\mathrm{TSI}_{\mathrm{TN}}$ & \multicolumn{2}{|c|}{69.65} & \multicolumn{2}{|c|}{70.10} & \multicolumn{2}{|c|}{67.83} & \multicolumn{2}{|c|}{66.95} & 68.63 \\
\hline TSI & \multicolumn{2}{|c|}{51.63} & \multicolumn{2}{|c|}{69.15} & \multicolumn{2}{|c|}{61.34} & \multicolumn{2}{|c|}{58.34} & 60.11 \\
\hline Trophic status & \multicolumn{2}{|c|}{ Eutrophic } & \multicolumn{2}{|c|}{ Eutrophic } & \multicolumn{2}{|c|}{ Eutrophic } & \multicolumn{2}{|c|}{ Eutrophic } & Eutrophic \\
\hline
\end{tabular}




\subsection{Diatom Community Composition}

A total of 46 diatom taxa within 16 genera were identified in the surface sediments of Dongping Lake. Aulacoseira, Ulnaria, Cyclotella, Navicula and Fragilaria were the most frequent species, most of which were epiphytic and planktonic, and Achnanthes, Amphora, Cymbella, Nitzschia and Gyrosigma also made up a significant part of the total composition. The diatoms showed a high diversity of taxa and abundance among different sampling sites. Aulacoseira ambigua, Fragilaria capucina. V. vaucheriea were dominant species in sites 7 , $8,9,10,16,21$ and 27. Diatom assemblages were most distinct in three sampling sites (sites 30,31 and 32) - the relative abundance of Gyrosigma acuminatum was $14.7 \%$ in sampling site $30 ; 15 \%$ of Surirella ovalis was in sampling site 31 and was nearly endemic to the three sites; and $13.1 \%$ of Nitzschia perminuta was nearly endemic to sampling site 32. Cyclotella meneghiniana was also mostly distributed in these three sampling sites. Aulacoseira ambigua, Aulacoseira granulate, Ulnaria ulna v. acus and Ulnaria tenera were distributed in nearly all the sample sites (Figure 3).

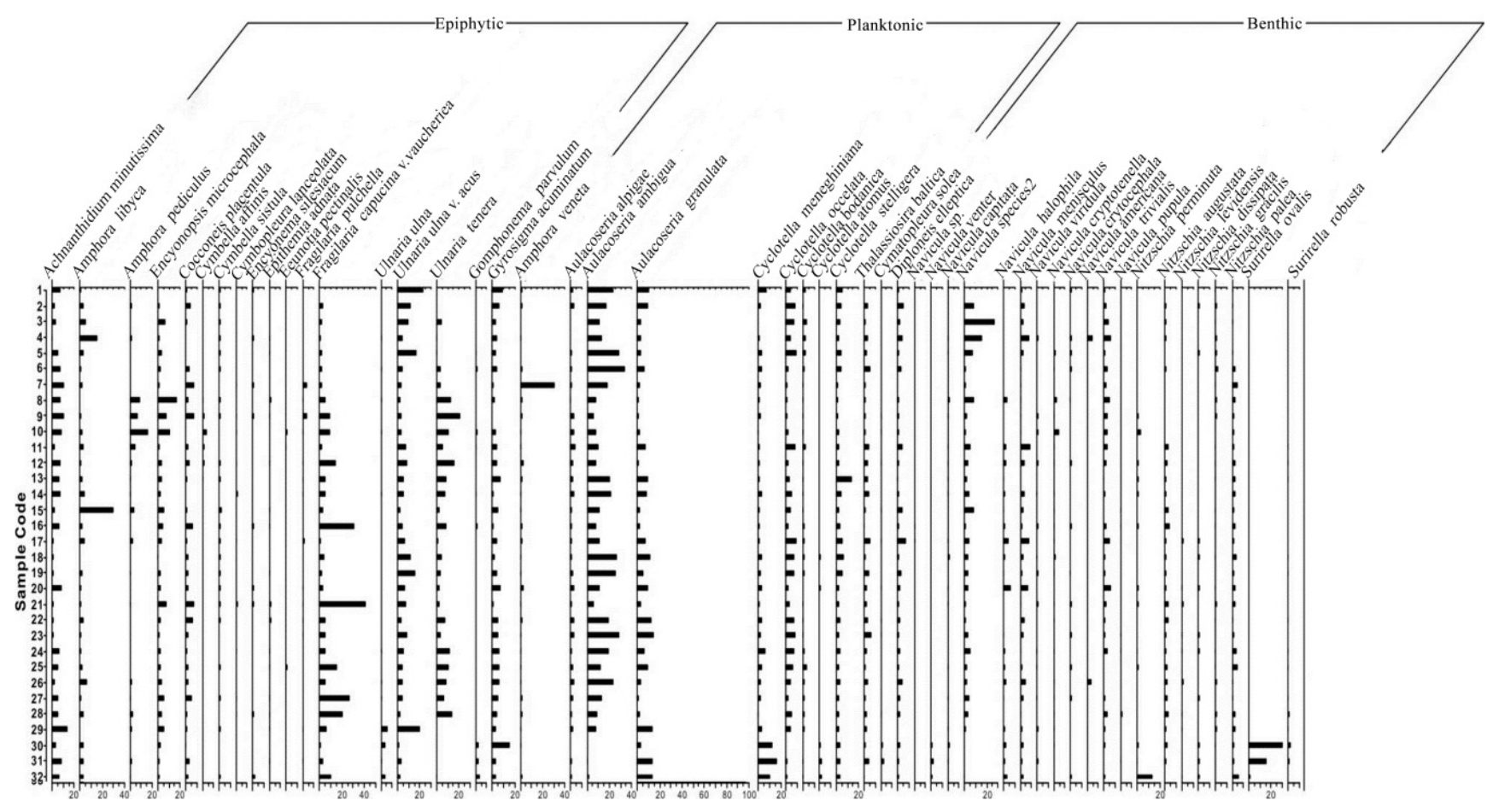

Figure 3. Relative abundances of diatom species from the 32 sampling sites in Dongping Lake.

\subsection{Redundancy Analysis}

The eigenvalues for the RDA axis explained $50.2 \%$ of the cumulative variance in the weighted averages of the diatom taxa, axis 1 explained $31.4 \%$ of the diatom community structure changes and axis 2 explained 16.6\%. The eigenvalues of the first four sorting axes accounted for $72.5 \%$ of the total eigenvalues, indicating a good sorting result. The Monte-Carlo permutation tests of the environmental variables indicate that $\mathrm{COD}(\mathrm{F}=2.0$, $p=0.038), \mathrm{pH}(\mathrm{F}=2.7, p=0.008), \mathrm{TP}(\mathrm{F}=2.1, p=0.028)$, conductivity $(\mathrm{F}=1.9, p=0.046)$ and transparency $(\mathrm{F}=1.8, p=0.038)$ were significant factors influencing diatom assemblage change. The sorting diagram of species-environment variables (Figure 4) showed that axis 1 demonstrated high conductivity and low transparency and featured Cyclotella ocellata, Navicula crytocephala, Ulnaria ulna v. acus, Aulacoseira ambigua, Aulacoseira granulate, Epithemia adnate and Nitzschia gracilis. Axis 2, with high COD, low $\mathrm{pH}$ and TP was concentrated in the Dongping Lake outlet area. These sites were dominated by Cyclotella meneghiniana, Navicula menisculus, Gyrosigma acuminatum, Ulnaria tenera, Navicula capitata, Nitzschia palea and Navicula cryptotenella. 


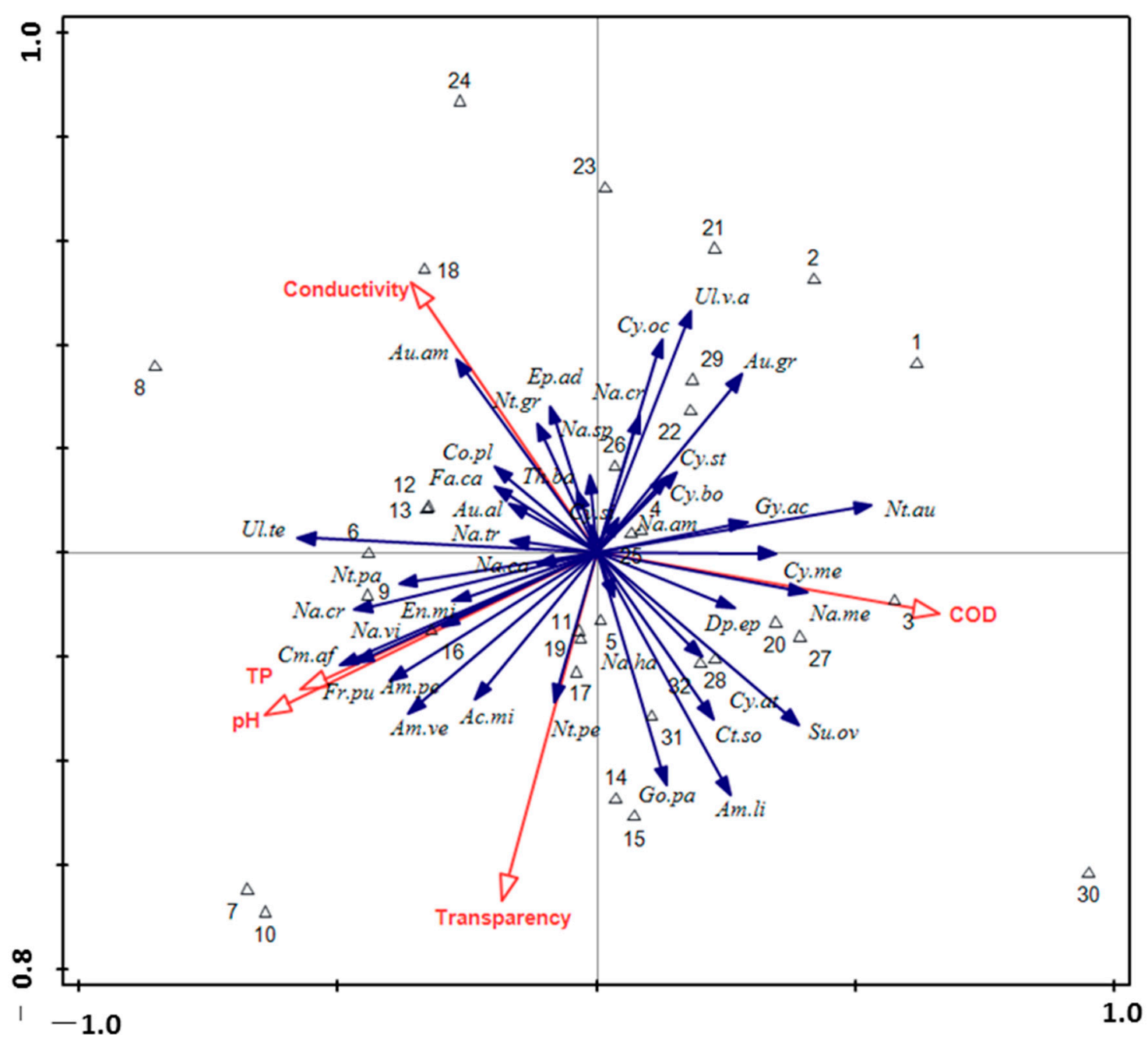

Figure 4. Results of the redundancy analysis (RDA) of diatoms, sites and environmental variables in Dongping Lake. (Ac.mi = Achnanthidium minutissimum; Am.li = Amphora libyca; Am.pe = Amphora pediculus; Am.ve = Amphora veneta; Au.al = Aulacoseira alpigae; Au.am = Aulacoseira ambigua; Au.gr = Aulacoseira granulate; Co.pl = Cocconeis placentula; Cy.me = Cyclotella meneghiniana; Cy.oc = Cyclotella ocellata; Cy.bo = Cyclotella bodanica; Cy.at = Cyclotella atomus; Cy.st = Cyclotella stelligera; Ct.so = cymatopleura solea; En.mi = Encyonopsis microcephala; Cm.af = Cymbella affinis; Cm.si = Cymbella sistula; Di.el = Diploneis elleptica; Ep.ad = Epithemia adnata; Fr.pu = Fragilaria pulchella; Fr.ca = Fragilaria capucina v.vaucheriea; Na.ca = Navicula capitata; Na.s $p=$ Navicula species; Na.ha = Navicula halophile; Na.me = Navicula menisculus; Na.vi = Navicula viridula; Na.cr $=$ Navicula cryptotenella; Na.cy = Navicula crytocephala; Na.am $=$ Navicula Americana; Na.tr = Navicula trivialis; Ul.v.ac = Ulnaria ulna v. acus; Ul.te = Ulnaria tenera; Nt.pe = Nitzschia perminuta; Nt.au = Nitzschia augustata; Nt.gr = Nitzschia gracilis; Nt.pa = Nitzschia palea; Su.ov = Surirella ovalis; Go.pa $=$ Gomphonema parvulum; Gy.ac $=$ Gyrosigma acuminatum; Th.ba $=$ Thalassiosira baltica)

\section{Discussion}

\subsection{Spatial and Temporal Characteristics of Water Environment}

The total nitrogen concentration of Dongping Lake was fairly stable between seasons, although there were some differences in the annual mean values at different sampling sites. The chlorophyll content and the total phosphorus concentration varied greatly in different seasons, with relatively little difference between sampling sites. Dongping Lake is mainly used for fish and crab breeding [20]; the spring and summer season is the peak season for the growth and reproduction of lake plants. The large input of fish bait is believed to be a factor leading to poor lake water quality. In addition, under the influence of the temperate continental monsoon climate, the precipitation in Dongping Lake is mainly concentrated in spring and summer. These are agricultural seasons, with high utilization of agrochemical 
and manures. In the cage aquaculture areas on the periphery of the lake, artificial breeding has polluted the water, resulting in the decomposition and deposition of the vegetation. Additionally, all fish and crabs have been experiencing increased metabolism from excess fish feed, which has caused a higher content of $\mathrm{N}$ and $\mathrm{P}$ in these regions compared to other areas [11,12]. Locations $\mathrm{d} 1, \mathrm{~d} 2$ and $\mathrm{d} 3$ were mainly ship mooring areas, and far from the sand dredging area, there was less pollution. Locations d11, d14, d15, d16, d20, d21, $\mathrm{d} 30, \mathrm{~d} 32$ were some distance from the cage areas and most of the sampling areas near the lake center, site $\mathrm{d} 21$, were more or less affected by the pollutants carried by the river entering the lake, whereas sites $\mathrm{d} 16, \mathrm{~d} 17$ and $\mathrm{d} 18$, being close to urban settlements, were influenced by human activity. The large number of cages in the vicinity of $\mathrm{d} 4-\mathrm{d} 9$ and d22-d29 were associated with pollution from feeding and organic waste pollution from the metabolism of organisms. These sources contributed to the high concentrations of nitrogen and phosphorus in this area.

Using principal component analysis (PCA) presenting all the datasets at the different seasons (Figure 5), transparency, Chla and TP were the dominant environmental factors in spring and summer. Transparency is mostly determined by the concentration of suspended solids in the water. Due to the spring cage culturing, some areas were affected by algae blooms which, along with their decomposed particles, can cause an increase in suspended solid concentrations, and thus reduce the transparency of fresh water [33]. In some samples, transparency values may be low (site 21, 22, 23, 24), because of the river scouring into the lake, wind and wave action and cage cultures. The water temperature in Dongping Lake varied significantly with time but not with station. During heavy rainfall in summer, input of nutrients to the lake leads to a high concentration of nitrogen and phosphorus. In addition, because of the high water temperature, lake internal circulation is accelerated and sediment releases nutrients to the overlying water [32]. TP concentration was higher at the water outlet (site $3,4,5,6,7$ ), perhaps because of the accumulation of nutrients from the inlet to the outlet. $\mathrm{NH}_{4}{ }^{+}-\mathrm{N}$ and COD were the dominant environmental factors in autumn and winter, indicating that the lake was being affected by exogenous inputDongping Lake has been greatly influenced by human activity, discharge of industrial sewage and cage culture [11,15]. The water $\mathrm{N}$ content was at a high level throughout the year $(1.74 \mathrm{mg} / \mathrm{L}$ in spring, $3.02 \mathrm{mg} / \mathrm{L}$ in summer, $0.53 \mathrm{mg} / \mathrm{L}$ in autumn, $1.44 \mathrm{mg} / \mathrm{L}$ in winter).

\subsection{Relationship between Diatom Community and Environmental Factors}

Species data are usually quite "noisy", and some species are sometime difficult to interpret because the diatom distribution in the surface sediments is not only controlled by their living habitat, but is also affected by regional current patterns and local freshwater discharge [34]. Sampling sites d16, d17, d21, d27 and d28 were dominated by Navicula menisculus, Gomphonema parvulum, Nitzschia palea and Fragilaria capucina var. vaucheriae, considered to be tolerant to eutrophication and organic pollution [8]. Surirella ovalis grows in alkaline environments with a high $\mathrm{SO}_{4}{ }^{2-}$ content [35], and the spatial distribution of this species centers around sampling sites 30,31 and 32 . We could infer that these sampling regions had high amounts of $\mathrm{SO}_{4}{ }^{2-}$, which is consistent with the water monitoring physicochemical index. Due to reduced rainfall and relatively large amounts of evaporation in recent years, some brackish freshwater diatom species now occur in Dongping Lake [36]. Aulacoseira ambigua and Aulacoseira granulata were the dominant species in cage aquaculture areas, which indicated that these regions were eutrophic [37]. March to June is the main period of vegetation growth in Dongping Lake. However, when we collected water samples in August, there were still some populations of species such as Potamogeton distinctus, Hydrilla verticillata, Nelumbo nucifera Gaertn, Najas minor, Zizania caduciflora and Phragmitis communis Trin, which could indicate that the water quality was good and that aquatic organisms developed well in Dongping Lake [22,38]. This is consistent with the fact that Fragilaria and Ulnaria prefer areas with abundant light and high transparency [39]. Submerged plants, such as Hydrilla verticillata, Vallisneria spiralis, Potamogeton malaianus, 
Ceratophyllum demersum and Myriophyllum spicatum, grow seasonally in different areas of the lake, and the transparency and chlorophyll content were significantly higher in these regions. The change in water depth not only means a change in lake water storage and heat capacity, but also can change the hydrodynamic process, chemical process and ecological process of the lake [40], altering the flow field distribution and wind wave characteristics of the lake, so as to change the water environmental capacity and self-purification capacity of the lake, thus affecting the structure of the aquatic biological community [41]. In recent years, due to low rainfall and relatively high evaporation in the basin, some species of diatoms in Dongping Lake prefer slightly alkaline fresh water.

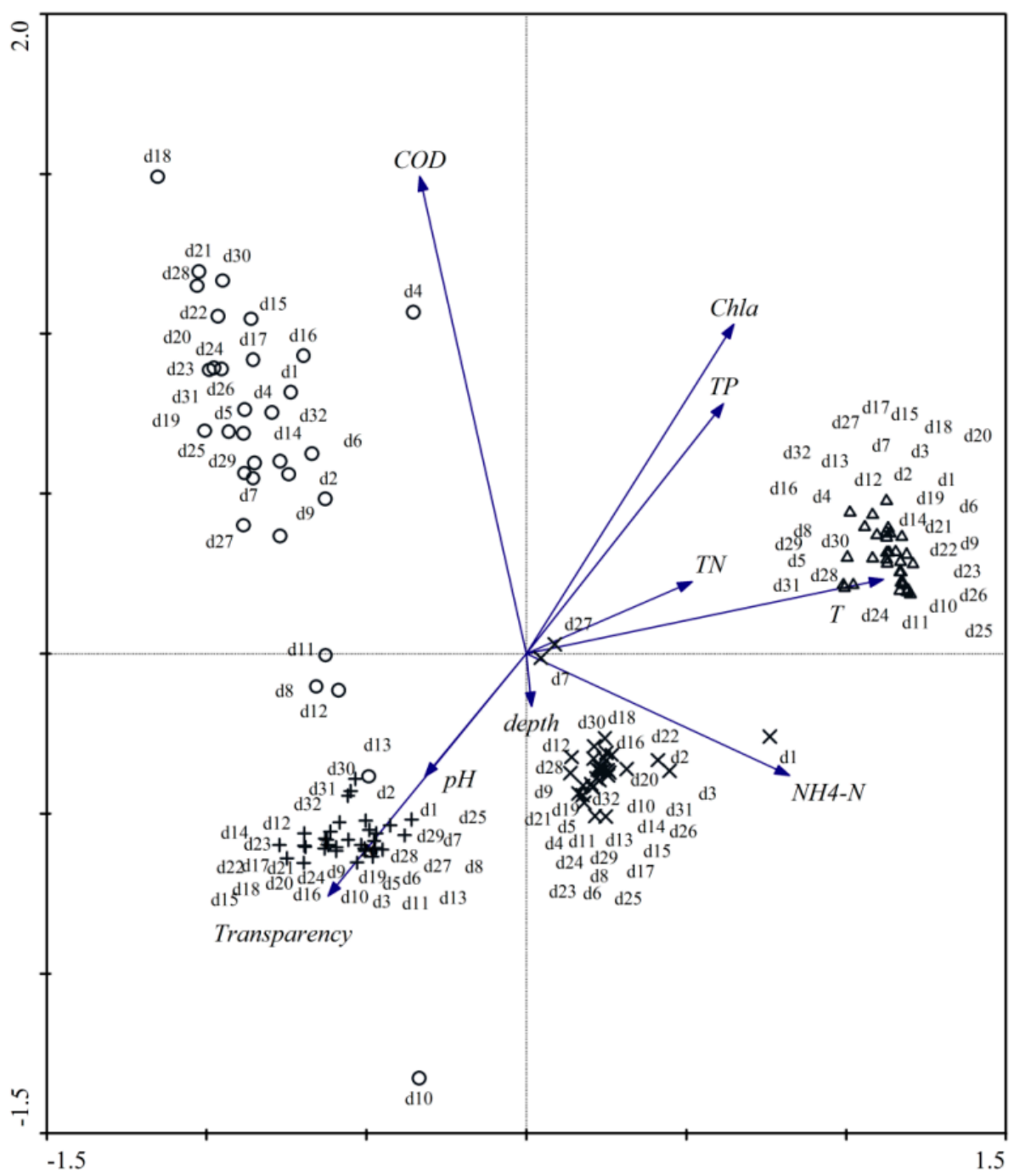

Figure 5. Results of principal component analysis (PCA) of environmental variables in different seasons (+: spring sampling sites, $\triangle$ : summer sampling sites, $\times$ : autumn sampling sites, $\bigcirc$ : winter sampling sites).

The results of the RDA analysis mostly reflected the relationship between the epiphytic diatoms and the environment in Dongping Lake. Transparency, COD, pH, depth and TP appear to be the most important factors, meaning that the distribution of the diatom assemblages was mostly influenced by nutrient composition, light intensity and ion concentrations. Epiphytic diatoms were affected by aquatic plants, and they were related to the water environment [42]. For example, Achnanthidium minutissima and Nitzschia palea are commonly attached to Myriophyllum verticillatum and Nelumbo nucifera Gaertn [37]; Navicula and Epithemia are commonly distributed among submerged plants or floating 
leaves [22]; and Navicula are mostly attached to Potamogeton crispus Linn and Potamogeton distinctus [4]. Some research has shown that Ulnaria and Fragilaria reflect the TP concentration $(<100 \mu \mathrm{g} / \mathrm{L})$ to some extent when they are the dominant species, meaning that the lake has not yet undergone eutrophication [43], so we could infer that some regions of Dongping Lake have not yet reached eutrophication. Aulacoseira ambigua and Aulacoseira granulata are the common species of eutrophic lakes in the middle and lower Yangtze River [5,44], and if the lake was in a eutrophic to hyper-eutrophic state, the abundance of these two species would decrease and their competitiveness would be relatively reduced. Moreover, research has shown that Aulacoseira are species with a high degree of silicatization and a high sedimentation rate, and they prefer to live in strongly disturbed water [6]. Moreover, Aulacoseira could be used to reveal the dynamic strength of the lake water. Therefore, from the distribution of Aulacoseira in Dongping Lake, it could be inferred that the water dynamic effect may be strong, which is consistent with the results of other studies $[13,14,45]$.

\section{Conclusions}

TSI showed that Dongping Lake was eutrophic in all seasons, but the water environment quality in different sampling areas was different, the inlet and cage breeding areas were seriously polluted and the center and outlet of the lake were relatively good. The dominant factors of water environment were different in different seasons; transparency, Chla and TP were the dominant environmental factors in spring and summer, and $\mathrm{NH}_{4}{ }^{+}-\mathrm{N}$ and COD were the dominant environmental factors in autumn and winter.

Epiphytic and planktonic species of diatoms were dominant, whereas benthic species were relatively rare in the surface sediments of Dongping Lake. Aulacoseira ambigua and Aulacoseira granulata had the greatest abundance, followed by Ulnaria and Fragilaria species. A redundancy analysis (RDA) and Monte Carlo permutation test revealed that $\mathrm{COD}(\mathrm{F}=2.0$, $p=0.038), \mathrm{pH}(\mathrm{F}=2.7, p=0.008), \mathrm{TP}(\mathrm{F}=2.1, p=0.028)$, conductivity $(\mathrm{F}=1.9, p=0.046)$ and transparency $(\mathrm{F}=1.8, p=0.038)$ were significant factors influencing diatom assemblage, suggesting that the distribution of the diatom assemblages was influenced by nutrient composition, light intensity and ionic concentrations. Although the distribution of the diatom community in the surface sediments showed that the water environment of some sampling areas was in good condition, the extensive use of cage aquaculture and industrial water discharge should receive more attention because it can pollute the water, as well as causing a large number of aquatic plants to decompose and be deposited in the sediments, resulting in a gradual depletion of aquatic plants and water pollution. This was a hidden danger to water quality and the safety of the South-to-North Water Diversion Project, which threatens to create a water shortage in North China.

Author Contributions: S.L. ran the statistical analyses, elaborated the data and wrote the manuscript; M.Y. made the algological analyses and made the chemical analyses; S.C. collected the samples and made the field measurements; X.Y. contributed its revisions. All authors have read and agreed to the published version of the manuscript.

Funding: This study was funded by the National Natural Science Foundation of China (41871073, and 41807430).

Institutional Review Board Statement: Not applicable.

Informed Consent Statement: Not applicable.

Data Availability Statement: The data presented in this study are available on request from the corresponding author.

Acknowledgments: We thank Xin Yao and Huanguang Deng for their assistance in the field sampling and analyses. Shiyong $\mathrm{Yu}$ is thanked for his patience and tremendous help with the writing and reasoning.

Conflicts of Interest: The authors declare that they have no conflict of interest. 


\section{References}

1. Mischke, S.; Herzschuh, U.; Massmann, G.; Zhang, C. An ostracod-conductivity transfer function for Tibetan Lakes. J. Paleolimnol. 2007, 38, 509-524. [CrossRef]

2. Marchetto, A.; Padedda, B.M.; Mariani, M.A.; Lugliè, A.; Sechi, N. A numerical index for evaluating phytoplankton response to changes in nutrient levels in deep mediterranean reservoirs. J. Limnol. 2009, 68, 106-121. [CrossRef]

3. Deng, J.; Cai, Y.; Chen, Y.; Zhang, L. Structure of phytoplankton community and its relationship with environment factors in Lake Honghu. J. Lake Sci. 2010, 22, 70-78. [CrossRef]

4. Dong, X.H.; Yang, X.D.; Liu, E.F. Diatom records and reconstruction of epilimnetic phosphorus concentration in Lake Taibai (Hubei Province) over the past 400 years. J. Lake Sci. 2006, 18, 597-604. [CrossRef]

5. Li, X.P.; Chen, X.H.; Dong, X.H.; Dong, Z.S.; Sun, D.P. Nutrient dynamics over the past 100 years and its restoration baseline in Dianshan Lake. Environ Sci. 2012, 33, 3301-3307.

6. Yang, X.; Wang, S.; Xia, W.; Li, W. Application of canonical correspondence analysis in the relationship between diatom and environment in lake of the Qinghai Tibetan Plateau. Sci. China Publ. House 2001, 31, 273-279.

7. Sun, J.L.; Liu, D.Y. The application of diversity indices in marine phytoplankton studies. Acta Oceanol. Sin. 2004, $26,62-75$.

8. Crossetti, L.O.; Bicudo, C.E.M. Phytoplankton as a monitoring tool in a tropical urban shallow reservoir (Garças Pond): The assemblage index application. Hydrobiologia 2008, 610, 161-173. [CrossRef]

9. Chen, Y.Y.; Chen, S.Y.; Yao, M.; Liu, J.Z.; Zhang, J. Sedimentary flux variation and environment of Dongping Lake during the last century. Acta Sedimentol. Sin. 2010, 28, 783-789.

10. Lu, X. The Research On Phytoplankton Community, Driving Environmental Factors and the Possibility of Cyanobacterial Bloom in Dongping Lake, China. Ph.D. Thesis, Shandong University, Jinan, China, 2013.

11. Lu, X.; Tian, C.; Pei, H.; Hu, W.; Xie, J. Environmental factors influencing cyanobacteria community structure in Dongping Lake, China. J. Environ. Sci. 2013, 25, 2196-2206. [CrossRef]

12. Chen, Y.; Chen, S.; Ma, C.; Yu, S.; Yang, L.; Zhang, Z.; Yao, M. Palynological evidence of natural and anthropogenic impacts on aquatic environmental changes over the last 150 years in Dongping Lake, North China. Quat. Int. 2014, 349, 2-9. [CrossRef]

13. Leng, C.M.; Gong, J.X.; Wang, Y.N.; Guo, J.F.; Li, X.Q.; Wang, Q.D. Analysis of phytoplankton biological quantity in Dongping Lake in 2007. J. Shandong Agric. Univ. 2009, 40, 513-516.

14. Zhang, J.; Deng, H.; Wu, A.; Chen, S.; Wang, D. Decomposition of Potamogeton crispus and its effect on the aquatic environment of Dongping Lake. Acta Sci. Circumst. 2013, 33, 2590-2596. [CrossRef]

15. Jiang, T.; Zhang, S.; Ding, C.; Liu, J.; Dai, X.; Xu, Y. Analyzing trends of chlorophyll-a concentration in Dongping Lake based on landsat image from 1985 to 2015. Environ. Monit. China 2018, 34, 137-144.

16. L<monospace $>\ddot{u}</$ monospace $>$, W.; Yao, X.; Zhang, B. Correlations between fluorescence characteristics of chromophoric dissolved organic matter and nutrients in Driver and Dongping Lake. Ecol. Environ. Sci. 2018, 27, 565-572.

17. Yu, S.; Sun, G.; Dou, S.; Ma, Y.; Ge, H. The declining of hydrophyte of Dongping Lake and the influence of the south-to-north water transfer project on it. China Environ. Sci. 2005, 25, 200-204.

18. Wang, Y.; Yang, L.; Kong, L.; Liu, E.; Wang, L.; Zhu, J. Spatial distribution, ecological risk assessment and source identification for heavy metals in surface sediments from Dongping Lake, Shandong, East China. Catena 2015, 125, 200-205. [CrossRef]

19. Liu, X.L.; Yao, X.; Dong, J.; Yao, M.; Zhang, J.; Deng, H. Water environment of Dongping Lake. Chin Agric. Sci. Bull. 2016, 32, 82-87.

20. Jiang, D.; Liu, C.; Liu, G.; Wang, W.; Liu, J. Analysis of the water environment in Dongping Lake and its vicinity. Trans. Oceanol. Limnol. 2002, 4, 12-15.

21. Tian, Z.Z.; Xing, Y.H.; Jiang, R.X.; Gao, Y. Distribution of phosphorus fractions in the surficial sediments of Dongping Lake. Resour. Environ. Yangtze Basin 2010, 19, 719-723.

22. Liang, L.L.; Yu, Q.Z.; Deng, H.G.; Liu, E.F.; Zhang, B.H.; Niu, Z.G.; Liu, J.Z. Spatio-temporal pattern of Potamogeton crispus L. in Lake Dongping based on NDVI time series. J. Lake Sci. 2019, 31, 529-538.

23. National Environmental Protection Agency of China (NEPAC). Standard Methods for the Examination of Water and Wastewater; Chinese Environmental Science Press: Beijing, China, 2002.

24. Battarbee, R.W.; Charles, D.F. Diatom-based pH reconstruction studies of acid lakes in Europe and North America: A synthesis. Water Air Soil Pollut. 1986, 30, 347-354. [CrossRef]

25. Krammer, K.; Lange-Bertalot, H. Bacillariophyceae, Teil 1: Naviculaceae; Gustav Fischer Verlag: Stuttgart, Germany; New York, NY, USA, 1986.

26. Krammer, K.; Lange-Bertalot, H. Bacillariophyceae, Teil 2: Bacillariaceae, Epithemiaceae, and Surirellaceae; Gustav Fischer Verlag: Stuttgart, Germany; New York, NY, USA, 1988.

27. Krammer, K.; Lange-Bertalot, H. Bacillariophyceae, Teil 3: Centrales, Fragilariaceae, and Eunotiaceae; Gustav Fischer Verlag: Stuttgart, Germany; New York, NY, USA, 1991.

28. Krammer, K.; Lange-Bertalot, H. Bacillariophyceae. 4. Teil: Achnanthaceae, Kritische Ergänzungen Zu Navicula (Lineolatae) und Gomphonema. Gesamtliteraturverzeichnis Teil 1-4; Gustav Fischer Verlag: Stuttgart, Germany; New York, NY, USA, 1991; Volume 2/4, p. 437.

29. Charles, R.K.; Patrick, L.B. A Carlson-Type Trophic State Index for Nitrogen in Florida Lakes. Jawra J. Am. Water Resour. Assoc. 2007, 17, 713-715. [CrossRef] 
30. Alain, M.; Pierre, L.; Daniel, B. Partialling out the spatial component of ecological variation: Questions and propositions in the linear modelling framework. Environ. Ecol. Stat. 1998, 5, 1-27. [CrossRef]

31. Ter Braak, C.J.F.; Smilauer, P. CANOCO Reference Manual and Cano Draw for Windows User's Guide: Software for Canonical Community Ordination, version 4.5; Microcomputer Power: New York, NY, USA, 2002.

32. Chen, X.; Yang, X.; Dong, X.; Liu, E. Effects of environmental changes on the succession of diatom assemblage during the last 50 years in Lake Chaohu. J. Lake Sci. 2011, 23, 665-672. [CrossRef]

33. Ouyang, L.L.; Pan, Y.D.; Huang, C.M.; Tang, Y.; Du, J.; Xiao, W.Y. Water quality assessment of benthic diatom communities for water quality in the subalpine karstic lakes of Jiuzhaigou, a world heritage site in China. J. Mt. Sci. 2016, 9, 1632-1644. [CrossRef]

34. Huang, Y.; Jiang, H.; Svante, B.; Li, T.G.; Lu, H.Y.; Ran, L.H. Surface sediment diatoms from the western Pacific marginal seas and their correlation to environmental variables. Chin. J. Oceanol. Limnol. 2009, 27, 674-682. [CrossRef]

35. Cüneyd, N.S.; Sophia, B.; Ács, É.; Hayri, D. Diversity and ecology of diatoms from Felent creek (Sakarya river basin), Turkey. Turk. J. Bot. 2012, 36, 191-203. [CrossRef]

36. Tian, C.; Lu, X.T.; Pei, H.Y.; Hu, W.R.; Xie, J. Seasonal dynamics of phytoplankton and its relationship with the environmental factors in Dongping Lake, China. Environ. Monit. Assess. 2013, 2, 2627-2645. [CrossRef]

37. Zelnik, I.; Balanc, T.; Toman, M.J. Diversity and Structure of the Tychoplankton Diatom Community in the Limnocrene Spring Zelenci (Slovenia) in Relation to Environmental Factors. Water 2018, 10, 361. [CrossRef]

38. Tian, C.C.; Wu, X.Q.; Feng, S.S.; Cai, Q.J.; Yang, T.T.; Xiao, B.D. Relationship between the distribution of submerged plants and environment factors in Dongping Lake. Environ. Sci. Technol. 2018, 41, 15-20.

39. Bernhart, O.R.; Renaut, R.W.; Muiruri, V.M.; Rabideaux, N.M.; Lowenstein, T.K.; McNulty, E.P. Quaternary history of the Lake Magadi Basin, southern Kenya Rift: Tectonic and climatic controls. Palaeogeogr. Palaeoclimatol. Palaeoecol. 2019, 518, 97-118. [CrossRef]

40. Wang, J.L.; Fu, Z.S.; Qiao, H.X.; Liu, F.X. Assessment of eutrophication and water quality in the estuarine area of Lake Wuli, Lake Taihu, China. Sci. Total Environ. 2019, 650, 1392-1402. [CrossRef]

41. Summers, J.C.; Kurek, J.; Ruhland, K.M.; Neville, E.E.; Smol, J.P. Assessment of multi-trophic changes in a shallow boreal lake simultaneously exposed to climate change and aerial deposition of contaminants from the Athabasca Oil Sands Region, Canada. Sci. Total Environ. 2017, 592, 573-583. [CrossRef] [PubMed]

42. Malkin, S.Y.; Sorichetti, R.J.; Wiklund, J.A.; Hecky, R.E. Seasonal abundance, community composition, and silica content of diatoms epiphytic on Cladophora glomerata. J. Great Lakes Res. 2009, 35, 199-205. [CrossRef]

43. Kirilova, E.P.; Cremer, H.; Heiri, O.; Lotter, A.F. Eutrophication of moderately deep Dutch lakes during the past century: Flaws in the expectations of water management? Hydrobiologia 2010, 637, 157-171. [CrossRef]

44. Yang, X.; Anderson, N.J.; Dong, X.; Shen, J.I. Surface sediment diatom assemblages and epilimnetic total phosphorus in large, shallow lakes of the Yangtze floodplain: Their relationships and implications for assessing long-term eutrophication. Freshw. Biol. 2008, 53, 1273-1290. [CrossRef]

45. Lu, H.H.; Chen, S.Y. Water environmental problems and its countermeasures of Dongping Lake Basin. Guizhou Agric. Sci. 2011, 39, 201-203. 